Лобанов А. А., д.військ.н., професор ${ }^{1}$;

Троцько В. В., к.військ.н., с.н.с.';

Черненко А. Д. ${ }^{3}$

1 -Кафедра управління військами Національного університету оборони України імені Івана Черняховського, Київ;

2 - Український науково-дослідний інститут цивільного захисту;

3 - Науковий центр сухопутних військ Національної академії сухопутних військ імені Петра Сагайдачного

\title{
Обгрунтування системи показників для оцінювання ефективності витрат на утримання і розвиток Збройних Сил України в інтересах забезпечення оборонної достатності держави на короткостроковий період
}

Резюме. У статті обгрунтована система показників для оцінювання ефективності витрат на утримання і розвиток Збройних Сил України. Для оцінювання пропонується використати типові структури, які входять до складу категорій оперативних (бойових) можливостей виконання завдань за всіма сценаріями реагування на загрози.

Ключові слова: витрати на утримання і розвиток Збройних Сил України, ефективність, система показників, оперативні (бойові) можливості.

Постановка проблеми. Удосконалення системи оборонного планування та раціональне витрачання бюджетних коштів в умовах сьогодення $є$ одним із пріоритетних завдань воєнної політики України. Не зважаючи на суттєве збільшення обсягів оборонного бюджету нарощування якісних показників оснащення i забезпечення Збройних Сил (3С) України залишається вельми проблематичним. Це обумовлено складною воєнно-політичною ситуацією довкола України та необхідністю вирішення цілого комплексу завдань, серед яких відбиття збройної агресії з боку Російської Федерації, вирішення питань взаємодії 3 державами НАТО і наближення стандартів України до стандартів цієї організації, здійснення якісної модернізації озброєння, забезпечення необхідної мотивації військовослужбовців та дотримання соціальних стандартів для них та членів їх сімей та ряд інших. Вирішення цих завдань забезпечить спроможності щодо досягнення необхідного рівня обороноздатності України в сучасних умовах, відповідно до вимог воєннополітичного керівництва країни $[1,2]$.

$$
\text { Підгрунтям для оцінювання }
$$
ефективності витрат на утримання і розвиток 3С України в інтересах забезпечення оборонної достатності держави на короткостроковий період могли б стати положення оборонного огляду в Україні [3], де наведено вичерпне визначення оперативних (бойових) можливостей або спроможностей. Згідно 3 цим визначенням - "Оперативні (бойові) можливості (спроможності) згруповані за певними категоріями кількісні i якісні показники здатності військ (сил) та засобів, що входять до складу сил оборони, 3 виконання завдань в операціях (бойових діях), які розраховані для типових умов та прийнятих стандартів їх виконання".

Відповідно до цього визначення оперативні можливості - це показники, що характеризують здатність військ (сил) та засобів 3 виконання завдань в операціях (бойових діях), які розраховані для типових умов та прийнятих стандартів їх виконання. Стосовно Збройних Сил України - це характеристика військових формувань, частин та підрозділів, що виконують завдання в умовах реалізації того, чи іншого сценарію їх застосування. Тобто можливості стосуються тільки сценаріїв застосування та Збройних Сил України. До них не входить здатність держави до забезпечення цих можливостей. Це характеризує інший пункт - “Обсяг потреб у ресурсах для досягнення необхідних можливостей (спроможностей) на довгострокову перспективу (5-10 років)”, додаток 11 [3], де зазначено, що "Матеріальною основою можливостей (спроможностей) $є$ такі 
елементи складу та організаційної структури сил:

озброєння та військова техніка (ОВТ); запаси матеріальних засобів;

військова інфраструктура (базування флоту та авіації тощо)".

Тобто в контексті короткострокового планування не розкриті такі питання:

1. Якою має бути система показників для оцінювання ефективності витрат на утримання і розвиток 3С України в інтересах забезпечення оборонної достатності держави на короткостроковий період?

2. Яким чином ця система повинна бути пов'язана із показниками короткострокового планування ресурсів та розподілу витрат в інтересах забезпечення оборонної достатності держави?

У зв'язку з цим обгрунтування системи показників оцінювання ефективності витрат на утримання i розвиток Збройних Сил України є актуальним науковим завданням.

Аналіз останніх досліджень i публікацій. Питання дослідження витрат на утримання і розвиток 3С України в інтересах забезпечення оборонної достатності держави розглядалися у роботах I.C. Руснака, М. М. Дєнєжкіна, В. П. Дідіченка, М. О. Слюсаренка, В. Х. Аскарова, I. М. Апаршина, В. В. Хоми, I. В. Лози та багатьох інших [4-9].

У цих роботах детально розглянуто ряд питань, пов'язаних з оборонним плануванням, зокрема питання результативності впровадження заходів, виконання програм, поєднання бюджетного процесу та заходів із планування тощо. У контексті ж оцінки ефективності короткострокового планування були розглянуті лише питання бюджетного формування, визначення цілей та послідовність їх досягнення у вказаний період. Питання ефективності витрат на утримання розглядалося тільки в контексті досягнення чи недосягнення поставленої мети. Дослідженню ж питань саме ефективності витрат на утримання та розвиток збройних сил сьогодні, на погляд авторів, приділяється недостатньо уваги. Однією зі складових дослідження ефективності витрат є обгрунтування системи показників оцінювання ефективності витрат на короткотривалий період оборонного планування.

Метою статті $\epsilon$ обгрунтування системи показників для оцінювання ефективності витрат на утримання і розвиток ЗС України в інтересах забезпечення оборонної достатності держави.

Виклад основного матеріалу. Система показників для оцінювання ефективності витрат на утримання і розвиток ЗС України в інтересах забезпечення оборонної достатності держави на короткостроковий період повинна бути пов'язана 3 єдиною системою оборонного планування, основою якого є оборонний огляд. Тому, використання категорій можливостей, визначених у керівному документі з проведення оборонного огляду в Україні [3] є логічним i беззаперечним. Послідовний розгляд цих категорій дасть змогу розкрити їх сутність та підійти до обгрунтування із системних позицій, чого в попередніх дослідженнях не було.

До першої категорії відноситься готовність військ (сил). Відповідно до визначення - "Готовність військ (сил) характеризує здатність щодо створення та утримання необхідної (достатньої) кількості військ (сил) для своєчасного i ефективного реагування на загрози (виклики) у прогнозованих ситуаціях, зумовлених змінами в обстановці, із забезпеченням можливості нарощування складу військ (сил) 3 використанням встановленої системи ступенів бойової готовності та проведення ротацій військ (сил), що будуть задіяні у поточних операціях (діях) для виконання завдань у ситуаціях. Включає також підготовленість особового складу до виконання завдань, його навченість та досвід для виконання завдань у прогнозованих ситуаціях" [3]. Сили та засоби, що забезпечують реалізацію можливостей за цією категорією - війська (сили) видів та родів військ Збройних Сил України. До військ (сил) зараховуються підрозділи або військові частини видів та родів військ Збройних Сил України, які за своїм призначенням повинні здійснювати реагування на загрози (виклики) безпеці України. Якщо проаналізувати витрати за цією категорією, то вони виглядатимуть так:

створення військ (сил) - витрати на формування з'єднань, військових частин, підрозділів: комплектування особовим складом; створення інфраструктури; оснащення військовою технікою та забезпечення боєприпасами; створення угруповань військ (сил);

утримання військ (сил) - витрати на утримання військ (сил): грошове забезпечення особового складу; підтримання озброєння та військової техніки у боєготовому стані; навчання та тренування особового складу (індивідуальна підготовка, оперативна 
підготовка, бойова підготовка); підтримання інфраструктури; ротація особового складу.

Слід зазначити, що категорія готовність військ(сил) характеризує всі без винятку сили та засоби Збройних Сил України, оскільки означає здатність виконувати завдання за призначенням всіма формуваннями та підрозділами (фактично здійснювати реагування на загрози (виклики) безпеці України).

Категорія “розвідка” - характеризує весь комплекс розвідувальних можливостей технічних, організаційних та інших, здатність щодо збору, обробки та своєчасного доведення достовірної інформації до керівництва для забезпечення ефективного ii використання у прогнозованій ситуації. Включає здатність щодо отримання інформації не тільки підрозділами чи структурами Збройних Сил, але й інших міністерств і відомств, включно 3 інформаційним обміном (наприклад, щодо природних чи техногенних аварій та катастроф). Сили та засоби, що забезпечують реалізацію можливостей за цією категорією військові частини та підрозділи, що здійснюють збір, обробку та доведення інформації.

Витрати на збір і обробку інформації розподіляються на утримання частин радіо- та радіотехнічної розвідки, військових частин космічної, повітряної та інших видів розвідки завданнями яких є збір і обробка інформації. Витрати на своєчасне доведення інформації створення i забезпечення оперативного, безпечного i ефективного функціонування системи обміну інформацією між Збройними Силами та іншими міністерствами та відомствами.

Ця категорія охоплює додаткові витрати на розвідувальні сили і засоби (військові частини), які входять, перш за все, до переліку типових формувань [2, додаток 8)].

Категорія "розгортання та мобільність” - характеризує здатність щодо своєчасного зосередження військ (сил) та засобів у визначеному місці (розгортання) та здійснення ними швидких переміщень під час виконання завдань у районі дій (мобільність), відповідно до умов прогнозованої ситуації. Передбачає можливість переміщення різними видами транспортних засобів та отримання доступу до них. Сили та засоби, що забезпечують реалізацію можливостей за цією категорією - військові частини та підрозділи, що забезпечують транспортування військ (сил), державні транспортні структури, інфраструктура. Витрати за категорією розгортання та мобільності наступні: облаштування території для здійснення заходів розгортання; створення засобів для виконання завдань мобільності та розгортання; вирішення питань взаємодії 3 іншими державними установами щодо вирішення питань транспортування для визначених ситуацій за сценаріями.

Категорія “застосування військ (сил)” характеризує здатність щодо ефективного застосування військ (сил), озброєння та військової техніки у будь-яких умовах обстановки, у першу чергу для виконання завдань за ситуаціями. Сили та засоби, що забезпечують реалізацію можливостей за цією категорією - системи озброєння і військової техніки та особовий склад (військові частини, підрозділи), здатний ефективно застосовувати OВТ для визначених ситуацій за сценаріями. Витрати за категорією застосування військ (сил): бойова, оперативна підготовка військ (сил); укомплектованість особовим складом із відповідною підготовкою; оснащеність озброєнням та військовою технікою, яка дає змогу ефективно застосовувати війська (сили) під час реалізації ситуацій за сценаріями.

Категорія “управління та зв'язок” вказує на здатність військ (сил) щодо організації та ефективного здійснення управління військами (силами) під час підготовки та в ході виконання ними визначених завдань у прогнозованих ситуаціях. Сили та засоби, що забезпечують реалізацію можливостей за цією категорією - військові частини (підрозділи), що забезпечують управління та зв'язок, технічні засоби та системи управління i зв'язку. Витрати за категорією: оснащеність військ (сил) засобами, системами зв'язку та інформаційними системами; оснащеність органів управління системами обробки інформації та відповідним програмним забезпеченням; здійснення заходів захисту інформації від ворожого втручання та порушення системи управління і зв’язку.

Категорія “логістика (тилове, технічне та медичне забезпечення)” - характеризує здатність щодо організації та ефективного здійснення своєчасного матеріальнотехнічного, медичного забезпечення виконання завдань у ситуаціях, у тому числі в операціях, бойових діях військ (сил) упродовж усього часу ïx ведення, для забезпечення досягнення мети їх застосування. Сили та засоби, що забезпечують реалізацію можливостей за цією категорією військові частини та установи логістики. Витрати за категорією: створення і зберігання 
матеріальних запасів у сховищах; створення військових медичних установ (військових частин, підрозділів), що здійснюють відновлення особового складу; організація і функціонування системи постачання.

Категорія "живучість та захист військ (сил)” - характеризує здатність військ (сил) зберігати бойову готовність та виконувати поставлені завдання в умовах вогневого впливу противника (включаючи застосування зброї масового ураження) та негативного впливу середовища, у тому числі наслідків природних і техногенних аварій та катастроф чи інших факторів, обумовлених прогнозованою ситуацією. Сили та засоби, що забезпечують реалізацію можливостей за цією категорією - військові частини інженерних військ, військ РХБ захисту, структури ДСНС України та інші установи. Витрати за категорією: створення системи фортифікаційних і захисних споруд; оснащення військ (сил) системами та засобами захисту i життєзабезпечення; взаємодія 3 іншими структурами, що виконують завдання цивільного захисту і ліквідації наслідків надзвичайних ситуацій.

Розглянуті категорії формують цілісну систему, що дає змогу реалізовувати ситуації за сценаріями. Взаємозв' язок між елементами цієї системи (категоріями можливостей) в контексті їх функціонування під час реалізації ситуацій за сценаріями наведено на рис. 1.

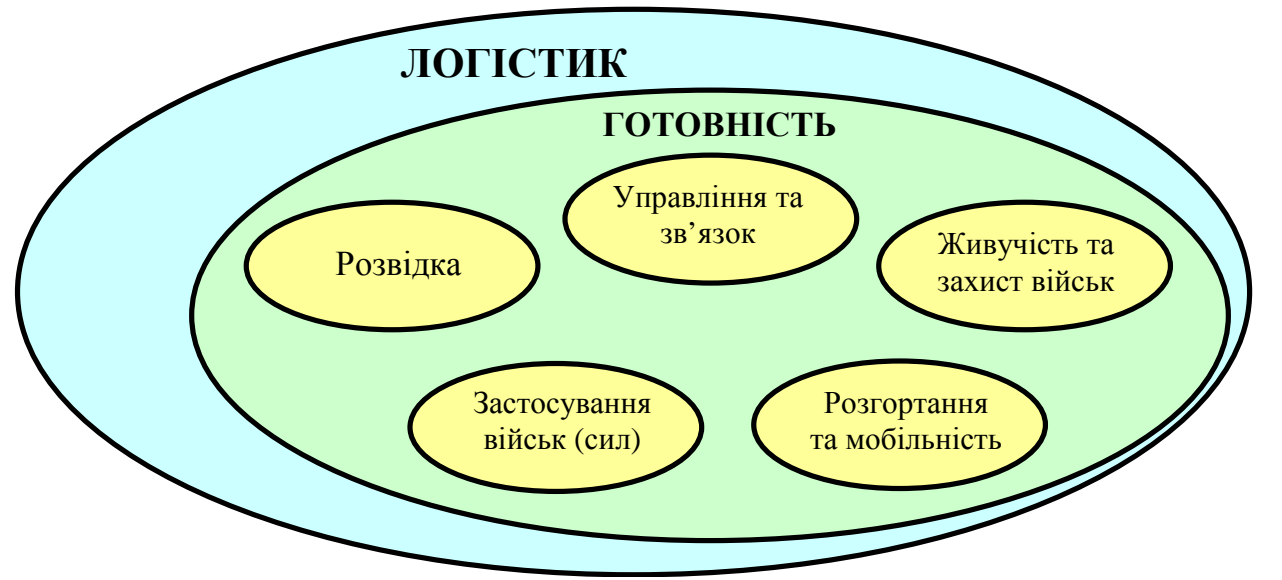

Рис. 1. Взаємозв' язок між категоріями можливостей в контексті їх функціонування під час реалізації

При цьому розподіл сил за типовими структурами кожної категорії наведено в табл. 1.

Розподіл сил за типовими структурами категорій можливостей

\begin{tabular}{|c|c|c|}
\hline № & Назви типових структур сил & Категорія можливостей \\
\hline 1 & Усі сили відповідно до ступенів готовності & Готовність \\
\hline \multirow{4}{*}{2} & Авіаційна бригада транспортна & \multirow{4}{*}{ Логістика } \\
\hline & Транспортний вертоліт & \\
\hline & Полк матеріального забезпечення & \\
\hline & Ескадрилья транспортних вертольотів & \\
\hline \multirow{5}{*}{3} & Бомбардувальна (розвідувальна) ескадрилья & \multirow{5}{*}{ Розвідка } \\
\hline & Радіотехнічна бригада & \\
\hline & Радіотехнічний батальйон & \\
\hline & Ескадрилья дистанційно керованих літальних апаратів (ДКЛА) & \\
\hline & Полк (бригада) ДКЛА & \\
\hline \multirow{5}{*}{4} & Авіаційна бригада транспортна & \multirow{5}{*}{ Розгортання та мобільність } \\
\hline & Транспортний вертоліт & \\
\hline & Ескадрилья транспортних вертольотів & \\
\hline & Інженерний полк & \\
\hline & Інженерний батальйон & \\
\hline \multirow[t]{13}{*}{5} & Авіаційна бригада тактичної авіації (ТА) (винищувальна) & \multirow{13}{*}{ Застосування військ (сил) } \\
\hline & Аеромобільна (повітрянодесантна) бригада (полк) & \\
\hline & Аеромобільний (повітрянодесантний) батальйон & \\
\hline & Артилерійський дивізіон & \\
\hline & Батальйон морської піхоти & \\
\hline & Батальйон радіоелектронної боротьби (РЕБ) & \\
\hline & Береговий протикорабельний комплекс & \\
\hline & Бомбардувальна (розвідувальна) ескадрилья & \\
\hline & Винищувальна ескадрилья & \\
\hline & Ескадрилья бойових вертольотів & \\
\hline & Механізована бригада & \\
\hline & Механізований батальйон & \\
\hline & Морська авіаційна ескадрилья & \\
\hline
\end{tabular}




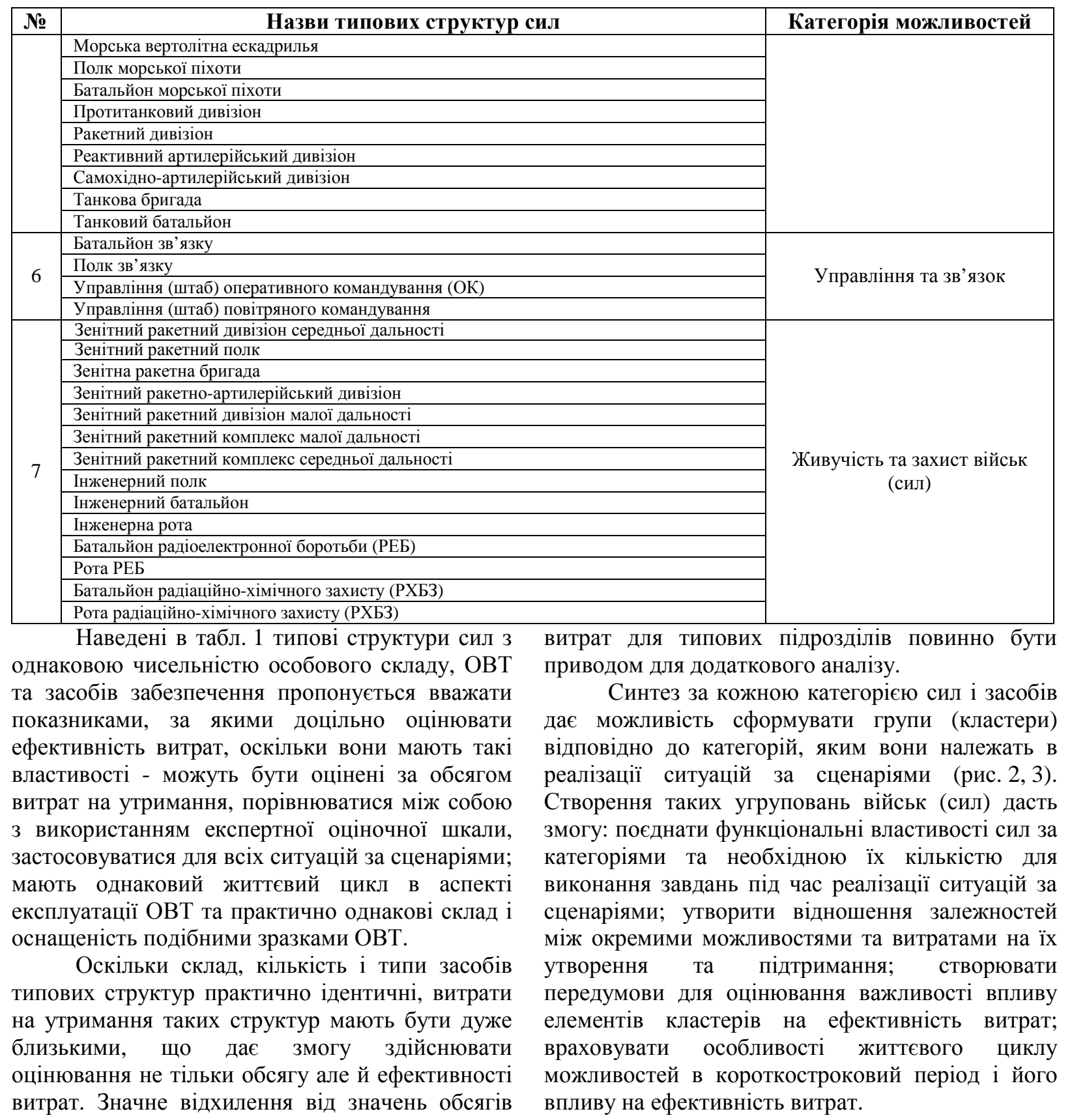

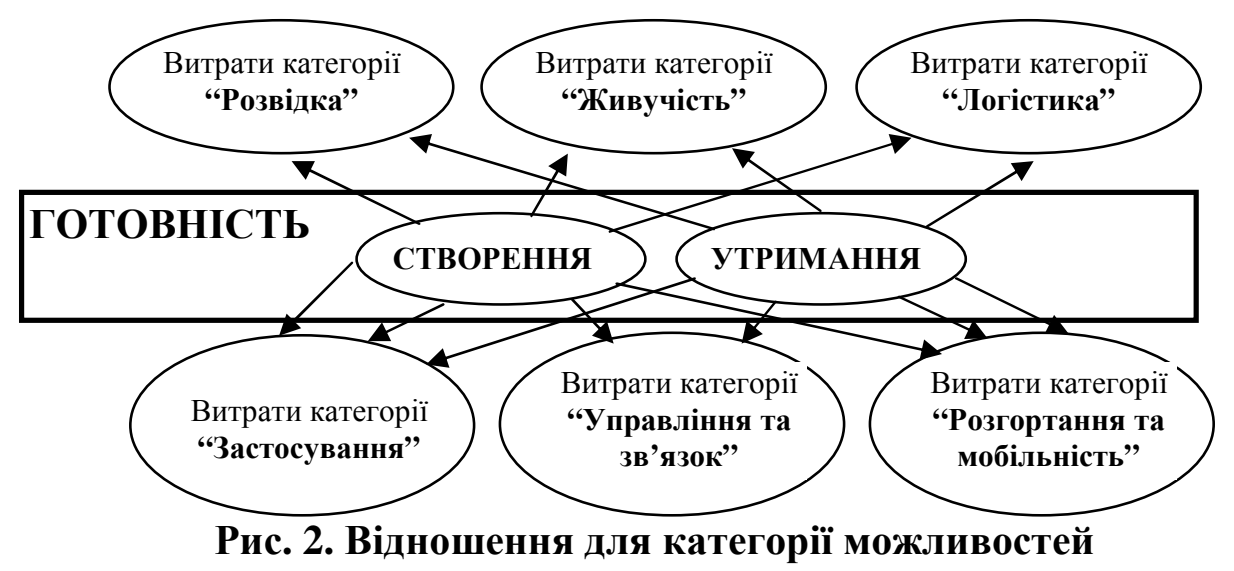



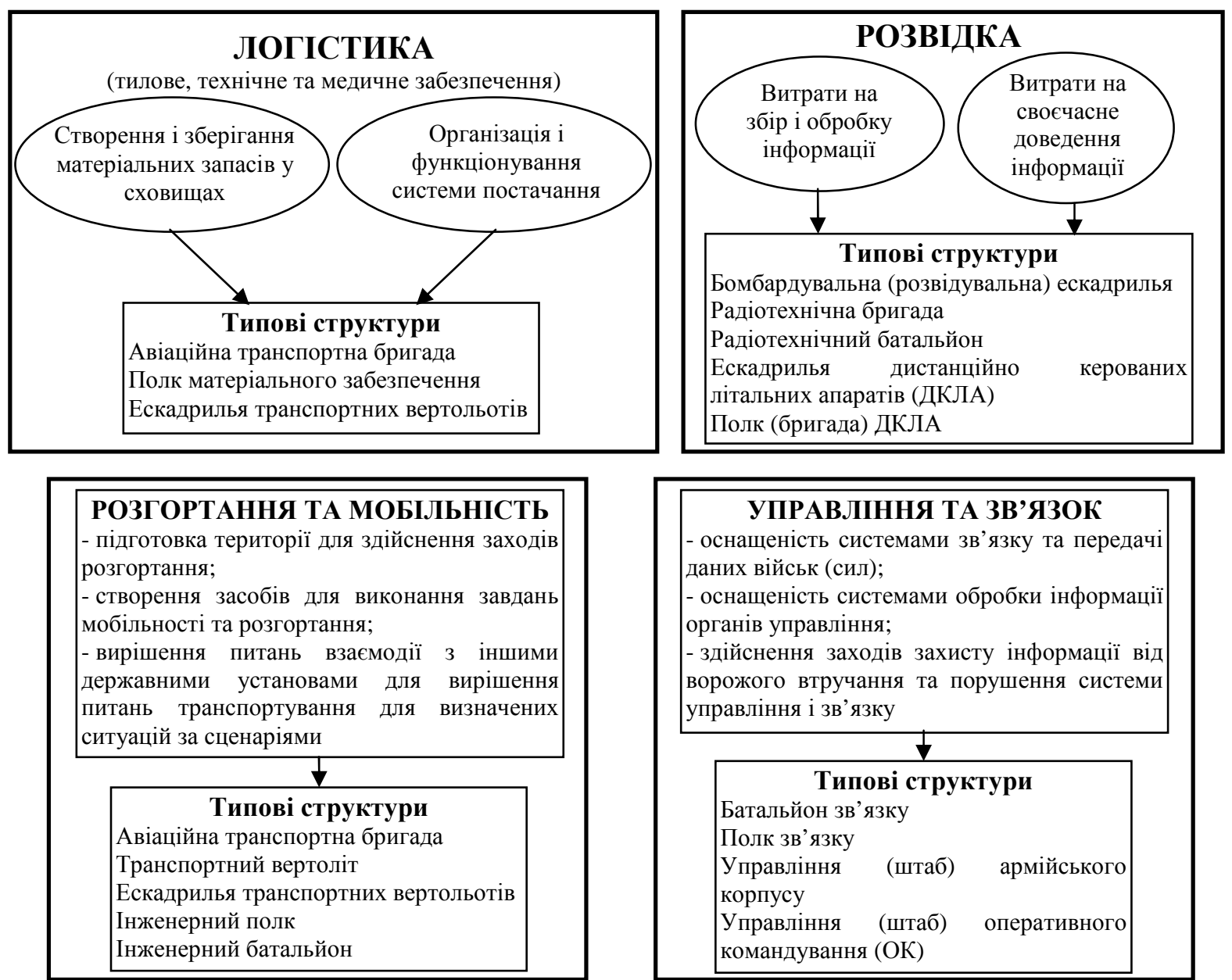

\section{ЗАСТОСУВАННЯ ВІЙСЬК (СИЛ)}

- оперативна, бойова підготовка військ(сил); - укомплектованість особовим складом 3 відповідною підготовкою;

- оснащеність озброєнням та військовою технікою, яка дає змогу ефективно застосовувати війська (сили) під час реалізації ситуацій за сценаріями

\section{Типові структури}

Авіаційна бригада тактичної авіації (ТА) (винищувальна)

Аеромобільна (повітрянодесантна) бригада (полк, батальйон)

Артилерійський дивізіон

Батальйон радіоелектронної боротьби (РЕБ)

Береговий протикорабельний комплекс

Бомбардувальна (розвідувальна) ескадрилья

Винищувальна ескадрилья

Ескадрилья бойових вертольотів

Механізована бригада (батальйон)

Морська авіаційна (вертольотна) ескадрилья

Полк (батальйон) морської піхоти

Протитанковий дивізіон

Ракетний дивізіон

Реактивний артилерійський дивізіон
ЖИВУЧІСТЬ ТА ЗАХИСТ ВІЙСЬК (СИЛ)

- створення системи фортифікаційних захисних споруд;

- оснащення військ (сил) системами захисту i життєзабезпечення;

- взаємодія 3 іншими структурами, що виконують завдання цивільного захисту i ліквідації наслідків надзвичайних ситуацій

\section{Типові структури}

Зенітна ракетна бригада

Зенітний ракетний дивізіон середньої дальності

Зенітний ракетний полк (дивізіон)

Зенітний ракетний дивізіон малої дальності Зенітний ракетний комплекс малої дальності Зенітний ракетний комплекс середньої дальності

Інженерний полк

Інженерний батальйон

Батальйон радіоелектронної боротьби (РЕБ)

Батальйон радіаційно-хімічного захисту (РХБ3)

Рис. 3. Відношення для категорій можливостей 
Висновок. Таким чином, використовуючи експертно-аналітичні методи дослідження запропонована система показників на основі переліку можливостей військ (сил) дасть змогу оцінити ефективність витрат на утримання та розвиток ЗС.

Кожна 3 категорій можливостей являє собою перелік сил, витрати на утримання яких у короткостроковий період можна оцінити шляхом аналізу сумарних витрат на типові структури, що входять до зазначеного переліку.

У разі утворення нових типових структур (для виконання певних (специфічних) завдань) перелік наведених структур у табл. 1 може бути розширений.

Напрям подальших досліджень полягає у розробленні методики оцінювання ефективності витрат на утримання та розвиток 3С України в інтересах забезпечення оборонної достатності держави на короткостроковий період.

\section{СПИСОК ВИКОРИСТАНОЇ ЛІТЕРАТУРИ}

1. Муженко назвав головне завдання для ЗСУ на 2017 рік [Електронний ресурс] // Режим доступу: http://expres.ua/news/2016/12/25/219664-muzhenko-nazvavgolovne-zavdannya-zsu-2017-rik

2. Міністерство оборони України Проектний офіс реформ. Набуття оперативних спроможностей. [Електронний pecypc] // Режим доступу: https://defensereforms.in.ua/operational-capabilities

3. Наказ Міністерства оборони України № 303 від 13.05.2013 "Про затвердження Рекомендацій 3 організації та проведення оборонного огляду” [Електронний ресурс] // Режим доступу: http://www.mil.gov.ua/content/other/ MOU303_2013.pdf

4. Проблеми проведення комплексного огляду сектору безпеки та оборони України: погляди на його організацію та вирішення завдань / М.М. Дєнєжкін, П.М. Крикун, І.С. Руснак // Наука і оборона. - 2014. - № 4. - С. 3-10.

5. Дідіченко В.П. Щодо оцінювання результатів виконання заходів програм розвитку Збройних Сил України за плановий період / В.П. Дідіченко, А.Ф. Савостьянов, О.М. Семененко, М.О. Слюсаренко // Зб. наук. праць ЦНДІ ЗС України. - К., 2010. - № 4 (54). - С. 33-45.

6. Аскаров, В.Х. Нові підходи до організації системи оборонного планування в Збройних Силах України / В.Х. Аскаров, С.С. Масловський // Оборонний вісник. - К., 2010.- № 1.- С. 6-12.

7. Апаршин I.M. Погляди на інтеграцію оборонного та бюджетного планування Збройних Сил України в єдину систему / І.М. Апаршин, М.М. Дєнєжкін // Наука і оборона. - 2007. -№ 1.- C. 24-32.

8. Хома В.В. Обгрунтування системи оборонного планування / В.В. Хома, І.В. Лоза // Військово-технічний збірник. - Вип. № 2 (11). - Львів : АСВ, 2014. - С. 99-103.

9. Лобанов, А.А. Методичний підхід до визначення складу сил і засобів Збройних Сил України та інших військових формувань під час проведення Оборонного огляду, що грунтуються на спроможностях / В.В. Троцько, Л.Г. Троцько // Збірник наукових праць Національного університету оборони України “Труди університету”. - К., 2012. - № 4 (110). - C. 21-26.

Стаття надійшла до редакції 02.03.2017

Лобанов А. А., Д.воен.н., профессор ${ }^{1}$;

Троцько В. В., к.воен.н., с.н.с. ${ }^{2}$;

Черненко А. Д. ${ }^{3}$

${ }^{1}$ - Кафедра управления войсками Национального университета обороны Украины имени Ивана Черняховского, Киев;

2 - Украинский научно-исследовательский институт гражданской защиты;

${ }^{3}$ - Научный центр сухопутных войск Национальной академии сухопутных войск имени Петра Сагайдачного

Обоснование системы показателей для оценивания эффективности расходов на содержание и развитие Вооружённых Сил Украины в интересах обеспечения оборонной достаточности государства на краткосрочный период

Резюме. В статье обоснована система показателей для оценки эффективности расходов на содержание и развитие Вооружённых Сил Украины. Для оценки предлагается использовать типовые структуры, которые входят в состав категорий оперативных (боевых) возможностей выполнения задач по всем сценариям реагирования на угрозы.

Ключевые слова: расходы на содержание и развитие Вооружённых Сил Украины, эффективность, система показателей, оперативные (боевые) возможности.

\section{A. Lobanov, Ds.M, professor ${ }^{1}$;}

V. Trochko, Ph.D ${ }^{2}$;

A. Chernenko ${ }^{3}$

${ }^{1}$ - Management department by troops of the National Defence University of Ukraine named after Ivan Chernyhovsky, Kyiv

2 - Ukrainian research institute of civil defence;

${ }^{3}$ - Scientific center of ground forces of the National academy of ground forces named after Petre Sahajdachny

Ground of the system of indexes for the evaluation of efficiency of charges on maintenance and development Armed Forces of Ukraine in interests providing of defensive sufficientness of the state on a short-term period

Resume. In the article the system of indicators for evaluating the effectiveness of spending on maintenance and development of the Armed Forces of Ukraine. For the evaluation of the proposed common structures that make up the category of operational (combat) capabilities assignments for all scenarios to respond to the threat.

Keywords: costs for maintenance and development of the Armed Forces of Ukraine, performance metrics, operational (military) capabilities. 